\title{
The Role of Gender and Relative Skills in Multitasking
}

\author{
Mürüvvet Büyükboyacı* \\ Middle East Technical University
}

\begin{abstract}
In this article, we examine individuals' multitasking behaviors and how multitasking affects their performance when they are faced with two different tasks and the tasks are complementary, i.e., multitasking is compulsory. First, we find that when individuals are switching between tasks in such an environment, the process of switching is affected by their gender as well as their relative skill in the tasks. In particular, whereas the frequency with which men and women switch between tasks is relatively similar when their skill levels are disparate, men tend to switch more frequently than women when their skill levels are relatively more balanced. Second, we find that while switching does not impact men's performance, it has a slightly negative impact on women's performance.
\end{abstract}

Keywords: lab experiment, task juggling, productivity, Weakest-Link Technology, multitasking, gender. JEL Classification: C91, J24, J16.

\section{Cinsiyet ve Göreli Yeteneklerin Birden Fazla İşle Uğraşmadaki Rolü}

\section{Özet}

$\mathrm{Bu}$ makalede, kişiler birbirini tamamlayan iki farklı görevle uğraşırken, yani birden fazla işle uğraşmak mecburi durumdayken, kişilerin davranışları ve bu durumun performanslarını nasıl etkilediği incelenmektedir. İlk olarak, bu ortamda kişilerin görevler arasında gidip gelme davranışının sadece cinsiyetlerinden değil, görevlerdeki göreli yeteneklerinden de kaynaklandığı bulunmuştur. Yani, kadın ve erkeklerin görevler arasında gidip gelme sıklığının bu kişiler iki görev arasında çok farklı yeteneklere sahipken benzer olduğu, kişiler görevlerde daha dengeli yeteneklere sahipken ise erkeklerin kadınlardan daha fazla görevler arasında gidip geldiği gözlemlenmiştir. İkinci olarak, görevler arasında gidip gelmenin erkeklerin performansını düşürmediği, kadınlarınkini ise çok az bir miktarda düşürdüğü gözlemlenmiştir.

Anahtar kelimeler: laboratuvar Deneyi, birden fazla görevle uğraşma, üretkenlik, En Zayıf Halka Teknolojisi, cinsiyet.

JEL Sinıflandirması: C91, J24, J16

\footnotetext{
* The research was funded by the European Commission under grant 2015ABH67840007. The author also thanks Andrea Robbett for her useful comments.

** Mürüvvet Büyükboyacı is an Assistant Professor in the Department of Economics at Middle East Technical Univerity, 06800,
} Cebeci, Ankara, Turkey. E-mail: muruvvet@metu.edu.tr 
$\mathrm{A}$ t home and at work, individuals must regularly juggle multiple tasks in order to succeed. For instance, consultants must advance multiple projects simultaneously, faculty must balance teaching and research requirements, and, across professions, individuals must juggle work and life obligations. Often, keeping these tasks in balance requires allocating varying amounts of time and effort to each task. We have designed an experiment to capture this "task-juggling" phenomenon (Coviello, Ichino, and Persico, 2014), which allows us to test how an individual's propensity to multitask is driven by gender and relative skill at each task.

Depictions in the popular media regularly portray women as inherently superior multitaskers: While men tend to work on tasks sequentially, women are more adept at switching between them (Pease and Pease, 2003; Fisher, 1999). As discussed by Buser and Peter (2012), however, there is little peer-reviewed research to support this conclusion. They report the results of a controlled experiment in which participants complete sudoku and word search puzzles either sequentially, on a schedule of their choosing, or on a schedule that forces them to switch between the two tasks unexpectedly. Rather than finding that women are more inclined or better suited toward multitasking, their results indicate that forcing participants to switch between tasks is similarly detrimental for both men and women and that, if anything, women are marginally less likely to multitask when given the option of organizing their own schedule.

We have conducted an experiment that allows us to test how the propensity to multitask is driven by gender and relative skill at each task. Our experiment differs from the literature in several ways. First, rather than requiring participants to spend equal amounts of time across tasks, participants can freely allocate their time however they choose. Second, the tasks are perfect complements, so that the individual must perform both to be productive. Third, our tasks are mechanical and equivalent to each other, which, relative to Buser and Peter (2012)'s puzzles, eliminates the cognitive benefits (looking at the problem with "fresh eyes") and the costs (recalling the problem) of switching. ${ }^{[1]}$ Instead, the primary benefit of switching between tasks is to ensure that time is allocated efficiently and both tasks are advancing at similar rates. Finally, we are able to carefully control individuals' skill levels at each task with a ball-catching game. ${ }^{[2]}$ In other words, participants may differ in their abilities to manage their time or to switch between distinct activities, but their skill level at each of the activities is known to both participant and experimenter. ${ }^{[3]}$

Contrary to conventional wisdom, we find that there is no difference between the switching behavior of men and women. This result dovetails with Buser and Peter

\footnotetext{
[1] We note that our design also shares similarities to Bracha and Fershtman (2013), in which contest participants complete two tasks, one of which is cognitively demanding, and can switch freely between the two. However, the tasks in their design are substitutable and they do not analyze switching behavior.

[2] The game will be described in detail in the Experimental Design and Procedures part. We basically used an updated version of the task used by Gachter, Huang, and Sefton (2015).

[3] Subjects learn their skills from their performance in the first stage (the piece-rate stage) which comes before the stage during which we measure multitasking behavior.
} 
(2012)'s finding, albeit in a different setting, and directly contradicts the notion that women are superior to men at switching between activities. However, we find that skill differences between the tasks impact men's and women's switching behavior differently. In particular, whereas the frequency with which men and women switch between tasks is relatively similar when their skill levels are disparate, men tend to switch more frequently than women when their skill levels are relatively more balanced. When we look at how switching affects men's and women's performance, we observe that while switching does not have an impact on men's performance, it has a slightly negative impact on women's performance. We think that this result stems from the fact that the tasks are mechanical, i.e., there is no cognitive cost of switching from one task to the other, and performing in both tasks is compulsory. We further find that participants tend to start with the task at which they are weakest.

\section{Experimental Design and Procedures}

The experiment was conducted at the METU-FEAS Behavioral and Experimental Laboratory (BEL) at the Middle East Technical University (METU). Overall, 192 $2^{[4]}$ undergraduate students at METU participated in the experiment. All sessions were computerized using z-Tree (Fischbacher, 2007). Twelve subjects were admitted to each of the computerized experimental sessions. First, all subjects collected red and blue balls sequentially according to the piece-rate performance scheme. ${ }^{[5]}$ In this stage, subjects learned their skill levels in the task. Then, all subjects participated in six identical 90-second periods. ${ }^{[6]}$ Throughout the experiment, payoffs were described in terms of "tokens," with 10 tokens corresponding to 1 Turkish Lira. On average, subjects earned 25.05 TL, including a 5 TL participation fee.

Participants completed a real effort task, which is based on the ball-catching game developed by Gachter, Huang, and Sefton (2015). In the original task, participants moved a "tray" horizontally on their computer screen in order to catch balls that fell vertically downwards. To create two distinct but otherwise identical tasks, we created two versions of the game: one in which the balls that the subjects caught were red and another in which they were blue. In order to produce output, participants needed to catch one of each type of ball. Specifically, a participant's output, x, was determined by $\mathrm{x}=\min \{$ Red Catches, Blue Catches $\}$. Participants could dynamically switch between the tasks as often as they liked by clicking the "Catch Red" or "Catch Blue" buttons

\footnotetext{
[4] For our analysis we used data collected from 110 men and 73 women, after excluding outlier subjects and subjects who could not produce a positive amount of output in the game, i.e., could not learn the nature of the game.

[5] At the beginning of the experiment, participants did not know the maximum number of red and blue balls that could fall during the initial 90 seconds. However, they could calculate/guess from the missed balls in the piece-rate stage. During that stage, subjects did not miss many balls. One of the referees pointed out that it might take longer for subjects to learn their skills while performing. Hence, we repeated our analysis by excluding the initial rounds of the contest stage. Our results did not change.

[6] There was one additional stage in the experiment, which is not related to this study.
} 
on their screen. When one task was open, the other disappeared and participants could not catch balls of the other type. This allowed us to observe each instance of switching between tasks and record the amount of time spent on each instance. Figure 1 presents a screen shot of the split screen ball-catching game.

Unlike the original Gachter, Huang, and Sefton (2015) task, the timing and placement of the balls in our experiment were hardwired, so that a specific number of balls always fell over the course of the 90 second period. The task was programmed so that any participant who is reasonably comfortable using a computer and mouse would be able to catch every ball that he or she saw. This eliminated the effects of innate participant skill or practice and allowed us to induce participant productivity in each of the two tasks. Using this method, we induced two participant skill types and randomly assigned one half of the subjects to each type. Type 1 participants had a productivity of 30 in Red (i.e., they could catch 30 red balls in 90 seconds) and 60 in Blue, while Type 2 participants had a productivity of 100 in Red and 25 in Blue. In other words, Type 1 individuals had a more balanced skill set relative to Type 2, allowing us to assess the impact of disparate skills on task juggling. However, the productivities were set such that both types could produce an identical output level if they divided their time efficiently. ${ }^{[7]}$

Figure 1

\section{Screenshot of our Ball Catching Game}

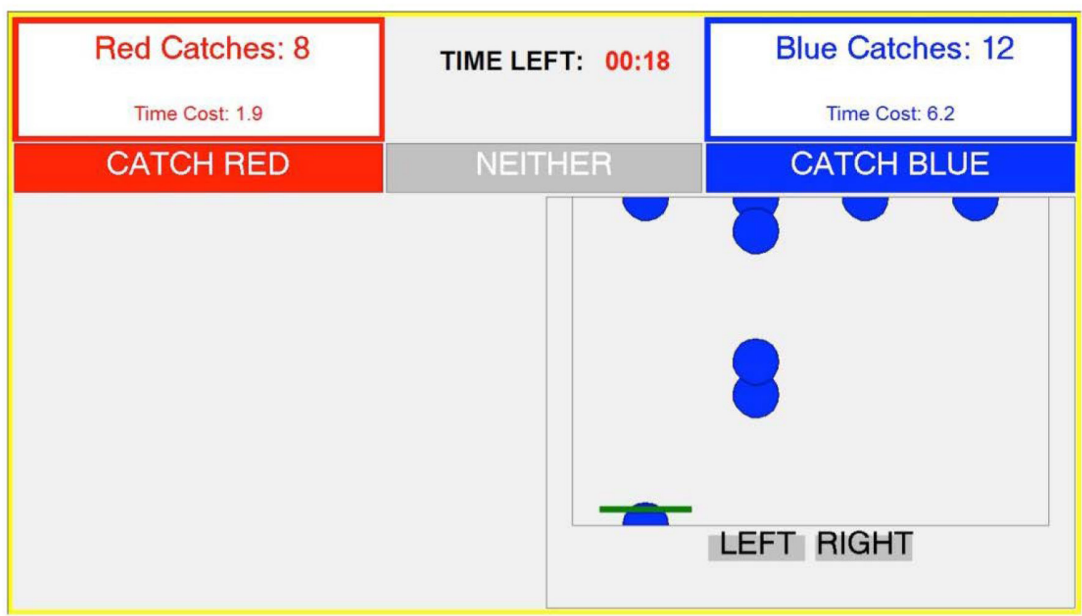

Since the subjects were more productive at one of the tasks than the other, they could not maximize their output by simply dividing their time equally across tasks. Instead,

[7] Type 1 s could collect $60 * 30 /(60+90)=20$, by separating $60 /(30+60)$ of their time on collecting red balls $(30 * 2 / 3=20)$ and $30 /(30+60)$ of their time on collecting blue balls $(60 * 1 / 3=20)$. Type $2 \mathrm{~s}$ could collect $100 * 25 /(100+25)=20$ for the given time period by separating $25 /(25+100)$ of their time on collecting red balls $(100 * 1 / 5=20)$ and $100 /(25+100)$ of their time on collecting blue balls $(25 * 4 / 5=20)$. 
they had to consider how much time to allocate to each task and, to maximize output, they had to devote more time to the task at which they were less productive. Specifically, Type 1 individuals maximized output when they spent $2 / 3 \mathrm{rds}$ of their time on their weaker task and 1/3 of their time on their stronger task, while Type 2 individuals maximized their output when they spent $4 / 5$ ths of their time on their weaker task and $1 / 5$ of their time on their stronger task. For each second that they spent catching balls in one of the two games, the participant paid a time opportunity cost of $0.27 .{ }^{[8]}$ Participants could also press the "Neither" button on their screen, which blanked both games and allowed them to avoid the cost. However, given that the marginal benefit of working was strictly greater than the marginal cost, participants did not have an incentive to shirk and very few spent more than a few seconds on "neither" during the 90 -second period.

Participants were paid based on how their output compared to that of a randomly chosen participant in the room. The likelihood of winning a prize was determined by a linear contest function (Che and Gale, 2000; Gill and Prowse, 2012; Gachter, Huang, and Sefton, 2015). Specifically, a participant with output $\mathrm{x}_{\mathrm{i}}$ competing against an opponent with output $x_{j}$ won a 200 token prize with probability: $\left(x_{i}-x_{j}+50\right) / 100$. They were matched with the same opponent for all six periods but did not receive feedback on their opponent's performance or behavior. Subjects were paid for one randomly selected period.

\section{Results}

We first considered overall performance. We restricted our analysis to subjects who switched between the tasks at least once (therefore producing a positive output) and, in doing so, eliminated observations in which the subjects did not understand the nature of the task.$^{[9]}{ }^{[10]}$ We expected participants of both types to produce 20 units of output, if they allocated their time efficiently across tasks. On average, Type1s produced 17.84 while Type 2 s produced 16.89 , indicating that individuals with more disparate skills were

[8] This was because they could have avoided this cost by clicking on the "Neither" button, shown in Figure 1. Every second spent on catching either red or blue balls cost 0.27 tokens, which were subtracted from subjects' earnings at the end of the period.

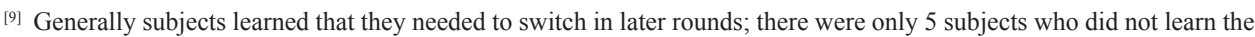
structure of the game in all rounds. We excluded these subjects' data totally in our analysis. Of those, 3 were women and 2 were men. Dropping these observations left us with 1015 subject-periods across 187 individuals, of whom 114 were men and 73 were women. We also dropped the outliers, or the most frequent switchers, from the data, which left us with 183 subjects of whom 110 were men and 73 were women.

${ }^{[10]}$ As one of the referees pointed out, if subjects switched between the tasks just once, the results were the same as when they performed the task "sequentially," as in one treatment of Buser and Peter (2012). In our experiment, which included 183 subjects, 135 switched between tasks more than once. When we compared the contest points obtained by subjects according to the number of switches, we did not observe any significant difference between when they switched between the tasks once or more than once. The average contest points of the subjects who switched between the tasks just once was 17.69 (the standard deviation was 3.88), and the average contest points of the subjects who switched between the tasks more than once was 17.08 (the standard deviation was 3.54). So, we cannot conclude that those who completed the tasks sequentially performed better than those who multitasked (or who switched more than once), as in Buser and Peter (2012) and Coviello, Ichino, and Persico (2015). 
significantly less productive (Wilcoxon-rank-sum test, $\mathrm{Z}=4.14, \mathrm{p}<.01$, individual is the unit of observation). Rather than finding that women performed better at this type of task, we found that men produced slightly more overall (Wilcoxon-rank-sum test, 17.61 vs. $17.04, Z=4.46, \mathrm{p}<.01)$. We did find, however, that having more disparate skills was harmful only for men (Wilcoxon-rank-sum test, $\mathrm{p}<.01$ ) and not for women (Wilcoxon-rank-sum test, $\mathrm{p}=.38$ ). The first two columns of Table 1 report the regression estimates of output on indicators for gender and type, and confirm these results with the exception of the superior performance of men.

We next considered whether switching frequency was associated with performance and whether this association differed by gender. Columns (3) through (6) in Table 1 report the estimates of regression models in which performance is regressed on the number of times the participant switches between tasks. We find that, while switching does not impact men's performance, it has a slightly negative impact on women's performance.

Table 1

The Determinants of Performance

\begin{tabular}{|c|c|c|c|c|c|c|}
\hline & $\begin{array}{l}\text { (1) } \\
\text { All }\end{array}$ & $\begin{array}{l}(2) \\
\text { All }\end{array}$ & $\begin{array}{l}\text { (3) } \\
\text { All }\end{array}$ & $\begin{array}{l}\text { (4) } \\
\text { All }\end{array}$ & $\begin{array}{l}(5) \\
\text { Male }\end{array}$ & $\begin{array}{l}(6) \\
\text { Female }\end{array}$ \\
\hline \multirow[t]{2}{*}{ Man } & 0.54 & $1.54 * * *$ & & & & \\
\hline & $(0.43)$ & $(0.57)$ & & & & \\
\hline \multirow[t]{2}{*}{ Type 2} & $-0.93 * *$ & 0.31 & $-0.94 * *$ & $-1.14 * *$ & $-1.74 * * *$ & 0.32 \\
\hline & $(0.43)$ & $(0.62)$ & $(0.43)$ & $(0.50)$ & $(0.58)$ & $(0.62)$ \\
\hline \multirow[t]{2}{*}{ Man*Type2 } & & $-2.04 * *$ & & & & \\
\hline & & $(0.85)$ & & & & \\
\hline \multirow[t]{2}{*}{ \#Switches } & & & -0.03 & -0.07 & -0.02 & $-0.05^{*}$ \\
\hline & & & $(0.04)$ & $(0.06)$ & $(0.05)$ & $(0.03)$ \\
\hline \multirow[t]{2}{*}{ \#Switches*Type2 } & & & & 0.07 & & \\
\hline & & & & $(0.06)$ & & \\
\hline \multirow[t]{2}{*}{ Constant } & $17.51 * * *$ & $16.88 * * *$ & $17.91 * * *$ & $18.02 * * *$ & $18.49 * * *$ & $17.00 * * *$ \\
\hline & $(0.41)$ & $(0.50)$ & $(0.28)$ & $(0.32)$ & $(0.29)$ & $(0.53)$ \\
\hline Observations & 991 & 991 & 991 & 991 & 598 & 393 \\
\hline Adjusted $\mathrm{R}^{2}$ & 0.02 & 0.04 & 0.02 & 0.02 & 0.05 & 0.01 \\
\hline
\end{tabular}

$* \mathrm{p}<0.10 ; * * \mathrm{p}<0.05 ; * * * \mathrm{p}<0.01$.

Standard errors clustered by individual are in the parentheses.

The next question was whether women were more likely to juggle tasks by switching between them and whether relative skills played a role in influencing switching behavior. In Table 2, we summarize the mean number of switching for men and women; and for Type 1 and Type 2. The table suggests that, on average, there was no significant 
difference between men's and women's switching behaviors when they had disparate skills. However, men switched more often than women when they had balanced skills (Wilcoxon-rank-sum test, $\mathrm{p}=0.079$ ).

According to these results, we can say that switching behavior was not only affected by gender but also by individuals' relative skills in the tasks. Contrary to common belief, while men's and women's switching behaviors did not differ when they had disparate skill levels, men multitasked more than women when they had balanced skill levels.

Table 2

The Number of Switches

\begin{tabular}{l|c|c}
\hline & Men & Women \\
\hline Balanced & $2.82(4.60)$ & $2.31(3.34)$ \\
\hline Disparate & $2.84(5.05)$ & $2.52(4.67)$ \\
\hline
\end{tabular}

Note: The table reports the mean number of switches for men and women, for each assigned type. Standard deviations are reported in the parantheses.

Finally, we observed a general behavioral tendency on the part of the subjects to start with the task at which they were weaker. Among Type 1 individuals, who were less productive in the red game, $60 \%$ began with red. Likewise, Type 2 individuals began with the blue game in $54 \%$ of our observations. As reported in the appendix, we ran a probit regression in which the decision to begin with the blue (right-hand side) game was regressed on indicators for type, gender, and period controls. We found that assigned productivity type significantly affected the participant's probability of beginning with the blue game $(\mathrm{p}<.01)$. In other words, subjects gave priority to the work at which they were weaker when the contest points were determined according to the minimum number of balls they collected in the tasks.

\section{Conclusion}

Situations in which individuals must complete multiple tasks in order to succeed are ubiquitous. In such situations, achievement in one task cannot substitute for accomplishment in another and individuals are likely to advance only if they do both jobs well. Further, individuals typically have different productivities in different tasks -for instance, a student may be good at math but bad at social sciences, a consultant may be strong at presenting but poor at data analysis, etc. In this paper, we address how the propensity to multitask is driven by gender and relative skill at each task. Without grounding in experimental research, popular culture has perpetuated the myth that women are especially adept at multitasking. In this environment, we found first that women chose to switch less frequently than men when their skill levels were balanced. Second, there was no significant difference between men and women when their skill levels were disparate. These results suggest that individuals' genders as well as their 
relative skill levels at a given task may affect their multitasking behavior. Finally, when we looked at the effect of switching on performance, we found that switching did not impact men's performance, and had a slightly negative impact on women's performance.

\section{References}

Bracha, A. and Fershtman, C. (2013). "Incentives: Working Harder or Working Smarter?" Management Science, 59(4): 771-781.

Buser, T. and Peter, N. (2012). "Multitasking,” Experimental Economics, 15(4): 641-655.

Coviello, D., Ichino, A., and Persico, N. (2014).”Time Allocation and Task Juggling," American Economic Review, 104 (2): 609-623.

Fischbacher, U. (2007). "Z-tree: Zurich Toolbox for Ready-made Economic Experiments," Experimental Economics, 10: 171-178.

Fisher, H. (1999). The First Sex: The Natural Talents of Women and How They are Changing the World. New York: Random House.

Gachter, S., Huang, L., and Sefton, M. (2016). "Combining 'Real Effort' with Induced Effort Costs: The Ball-catching Task," Experimental Economics, 19(4):687-712.

Pease, A. and Pease, B. (2003). Why Men can Only Do one Thing at a Time Women Never Stop Talking. Bucharest: Orion.

\section{Appendix}

Table 3

The Likelihood of Starting with the Blue Task

\begin{tabular}{l|c}
\hline & $(1)$ \\
\hline Type2 & $\begin{array}{c}0.36^{* * *} \\
(0.13)\end{array}$ \\
\hline Man & 0.13 \\
& $(0.13)$ \\
\hline Period & -0.001 \\
& $(0.02)$ \\
\hline Constant & $-0.33^{* *}$ \\
& $(0.17)$ \\
\hline Observations & 991 \\
\hline $\mathrm{R}^{2}$ & 0.02 \\
\hline
\end{tabular}

Standard errors are in parantheses. Standard errors are clustered by individuals. The reported values are coefficients. 